\title{
An Exploration of the Artistic Forms and Cultural Connotations of Russian Folk Embroidery
}

\author{
Yuyun Wang \\ Heihe University \\ Heihe, China
}

\author{
Yuxia Lu \\ Heihe University \\ Heihe, China
}

\begin{abstract}
This paper expounds the profound cultural connotation contained in the appearances of Russian folk embroidery through the aspects of artistic form, implication, dyeing method and craftsmanship.
\end{abstract}

\section{Keywords—folk embroidery; artistic form; exploration}

\section{INTRODUCTION}

Russia is a multi-ethnic country with rich folk art resources and profound religious traditions, of which textile embroidery is one of the Russian folk art. Torzhok of Kalininhas been famous for its embroidery since the 13th century and the most exquisite embroidery is the robe. After the October Revolution, many of the Soviet rank designs were embroidered here, and Mustang Joel town in Vladimir is known as the plain embroidery with little flowers and colored embroidery with big flower.

\section{THE OVERVIEW OF RUSSIAN FOLK EMBROIDERY}

In the north of Russia, in the long and snowy winter, the walls of the farmhouse are often decorated with bleached burlap kerchief with red pattern, which illuminates the dark and large farmhouse with its special warm color; people also like to drape the kerchief on the body or tie it to the head when participating in the wedding to increase the festive atmosphere of wedding; In addition, in the family festival and sacrificial activity, the main items are embroideries. The quality of the embroidery is a measure to weigh the merits of women, and the finest brodeuses are considered the best bride in the village. The embroidery such as shirts, men's jackets and aprons brought by every girl who are about to marry to the husband's house should not be less than two dozen. At the wedding, people are arranged to visit the bride's dowry, and the guests can evaluate the bride's craft and the degree of love to labor. Therefore, the Russian girls generally begin to learn embroidery craft from the age of seven. The circular pattern of flowers is a sign of the sun, a symbol of the source of heat and light. The tree that occurs most often in the embroidery is the tree of life, meaning integrating the gods, people and the world of dead ancestors into one, so as to achieve the eternal cycle of life and death.

This article is one of the results the Education research business costs of Heilongjiang Provincial Department - Russian Far East think tank research special project: "research on Russian Far East folk art image" project number: 18KYYWFZK02.
Russian Embroidery is characterized by the combination of practicality and beauty of the appearance, each piece of embroidery is not only easy and reasonable to use, and decorated with people, animals, birds and other patterns, which contains a variety of story content with a very strong artistic appeal. Patterns on embroidery are generally geometric shapes, with the edge of it embroidered with a variety of lace, and the middle part embroidered with patterns of more complex plot, such as people, trees, flowers, horses and birds. And these things often have the religious and folklore meaning.

\section{THE COLORING METHOD OF RUSSIAN FOLK EMBROIDERY}

There are two main coloring methods of Russian embroidery, one of which is the most widely used dyeing (conventional dyeing), mainly processing the textile in the chemical dye solution. Another method is to use paint by making the paint into tiny insoluble colored particles to adhere to the fabric (fiber raw material dyeing is not included in this type). Embroidery dyeing can be carried out at any stage including fiber, yarn, fabric and clothing.

\section{A. Loose Fiber Dyeing}

Fiber or loose fiber dyeing before spinning takes place at the appropriate temperature in a large dye tank. Most of the colored spun yarn adopts the loose fiber dyeing method (there are different effects of single fiber dyeing), which is commonly used in woolen wool fabric.

\section{B. Wool Top Dyeing}

This belongs to the fiber dyeing before the fiber becoming yarn, and its goal is to get a soft color mixing effect, the same to that of loose fiber dyeing. Wool top dyeing is generally used for combed wool yarn and wool fabric.

\section{Yarn Dyeing}

Dye the yarn before weaving, which is generally used for color fabrics, sweaters, etc. or directly using yarn (sewing thread, etc.). Yarn dyeing is the basis of embroidery. There are three methods of conventional yarn dyeing: 1. hank dyeing - immersing the loose yarn in a specially crafted vat, which is one of the most expensive dyeing methods; 2 . cone dyeing — wrapping the yarn of cone dyeing in a tube with 
holes, and then putting a lot of tubes into the dyeing tank, so the dyeing liquid circulation. The fluffy effect and softness is not as good as that of hank dyeing. 3. Warp beam dyeing is a large-scale package dyeing. Warp beam should be made before woven manufacturing (warping), and then the yarns of the entire warp should be dyed, such as the combination of paddle machine and warp beam yarn dyeing. Since it is warp beam, this method is more suitable for woven dyeing. However, with the emergence of the warp beam doff, we can make the dyed yarn on the warp beam the cheese, so that the range of use of this dyeing yarn is more extensive. The reduction dying method mostly used by indigo dyeing can only be well solved by using warp beam dyeing. If there is no warp beam doff, it is difficult to realize.

\section{Piece Dyeing}

The method of dyeing the fabric is piece dyeing. The commonly used methods are rope dyeing, jet dyeing, jig dyeing, pad dyeing (not tie-dye) and warp beam dyeing. Here we don't introduce one by one.

\section{E. Finished Embroidery Dyeing}

The clothes should be put into the nylon bag, and a series of bags are put into the vat together. Then they are mixed in the vat continuously (paddle dyeing machine).

\section{THE EMBROIDERY METHOD AND TECHNOLOGY OF RUSSIAN FOLK EMBROIDERY}

Diverse embroidery techniques of various peoples fully demonstrate the wisdom and creative thinking of woman of all ethnic groups, implying the romantic feelings deep in their hearts.

The variety of acupuncture methods of Russian folk embroidery also contributes to the colorful and different kinds of embroidery artwork. The embroidery method commonly used among the people includes flat embroidery, pan embroidery, lock embroidery, mesh embroidery, pull embroidery, chop embroidery, braided embroidery, barbola, and cut and paste embroidery. Some embroidery methods are unique to some certain peoples and later absorbed by other peoples, forming the scenery of thousands of purple and red flowers blooming. The embroidery methods above, as the name suggests, are explored and completed in the long-term practice of various peoples.

For example, the most common flat embroidery make the embroidery full bright and vivid with fine needle stitching; lock embroidery, mesh embroidery and barbola intensively reflect the wisdom of women from various peoples. The lace decorative effect of lock embroidery, three-dimensional hollow effect of mesh embroidery and slight embossing effect of barbola amaze people. These superb skills combined with the artistic techniques of freehand work, exaggeration, symbolization, and transformation make embroidery art more exquisite.

For instance, flowers with highest frequency of occurrence are often exaggerated to show the bloom part, so every pieces of petals have delicate color, from deep to shallow and even intermediate color are used to the make overall shape lifelike. And the branches and leaves are all simple, but vivid magpie, butterflies or birds are decorated in the branches or next to flowers, which can not only form a sharp contrast to the flowers but also reflect the beauty of flowers, making the whole composition with distinct levels. Bright colors and strong contrast result in a strong sense of beauty, which is related to the warm and unconstrained temperament of the plateau nation.

For instance, the embroidery made by Barbola techniques has bright colors and vivid patterns, and applies gold and silver thread, presenting a magnificent style; some of the embroidery has bright colors with sharp contrast, which is delicate and durable, showing the vivid and ancient characteristics; some of them have fine stitch, bright color, which are very beautiful; this embroidery method is simple and pure and full of affection, but it basically retain the common feature of exquisite work and the pursuit of bright and beautiful aesthetic effect.

\section{THE MORAL OF RUSSIAN FOLK EMBROIDERY}

In the Russian folk embroidery, the image of women with hands upraised or holding the horses with knight often appears which reflects the image of the earth mother and the whole nature. The rounded pattern of roses is the sign of the sun since a long time ago, among many ethnic groups including the Central Asian inhabitants; this is the symbol of the source of the sun, heat and light. The artwork painted with horses, birds and other mammals is the inherent tradition of the art of the Volga River, Siberian and Far East peoples. The mission of folk art is to beautify people's lives, which determines its topics and the plot, so it must be the organic combination of brilliant decoration, beautiful patterns and a variety of distinctive and bright colors. Therefore, folk art should be regarded as a complex and multidimensional field in the national art system. It is the same as the folk literature (oral literature) with a wide variety, becoming a large concept. From this special significance, it should be regarded as the art of the creation of daily necessities, which belongs to the category of productive art as well as a special form of beautiful practical crafts. Therefore, from the perspective of cultural connotations, the moral of Russian folk embroidery is analyzed as follows:

\section{A. Moral of Animal Patterns in Russian Folk Embroidery}

The artwork embroidered with horses, birds and other mammals is the inherent tradition of the art of the Volga River, Siberian and Far East peoples. The image of horses implies protecting the people, which can bless the harvest of agriculture and fertility of the land. The horse is generally embroidered the side part, with curved neck and the horse mane erect, which implies that the animal is very friendly with the people. The pattern of birds indicates that spring comes. According to the customs of Russian people, the lark is a sign of spring. In the embroidery with plot, there are often birds with some kind of badge logo, such as doubleheaded eagle (one body, two heads in different directions), which implies people's belief in the gods. They are used to 
ward off evil spirits in the event of a disaster (such as epidemic, drought, and hail).

\section{B. Moral of the Figures Pattern in Russian Folk Embroidery}

The images of man in Russian folk embroidery are always the front side, and the heads are embroidered into a diamond-shaped or octahedron. The image of women with hands upraised or holding the horse with knights on it also often appear in embroidery. Women are all the ancestors of the world as well as the great goddess, so the embroidery embodies the image of the earth mother and the whole nature. In the peasant embroidery, the knights are often embroidered into the envoy with the archery in hands, or holding a small branch, who sent bright to the earth, bringing the harvest of food.

\section{Moral of Floral Pattern in Russian Folk Embroidery}

Some of the patterns of Russian folk embroidery are often repeated several times, and some lace patterns are often embroidered by repeating small birds and trees for several times, which indicates the endless reverie to the beautiful world of Russians. There are not many traditional colors of embroidery, which are generally the hue full of deepness. There are two basic colors: red and black and dark gray and dark blue. Other colors are added in the picture only as added colors.

Since the beginning of the 20th century, folk embroidery has absorbed new and non-traditional patterns and episodes from the city, such as a bunch of roses, cornflowers and chamomile carefully drawn according to the natural shape, a herd of parrots and birds and some realistic scenes in life. Embroidery can be embroidered by cotton thread, silk thread, wool as well as gold and silver thread embroidery. The technology of using gold and silver thread to embroider has emerged as early as in the era of Kiev Lucy, when the goldplated gold and silver thread are used in embroidery, and later the wire twisted to flax or silk. In addition to the spinning thread, metal wire; gold and silver thread and metal sequin are also used. The main advantage of elaborate embroidery with metal wire is sparkling, and the threedimensional of the pattern on the surface is strong. Using ordinary thread to embroider a flat graphics on the cloth is "plain stitch embroidery." Embroidered another layer on the birch bark or the pattern of paper can make the pattern protruding, called "embroidery according to the figure". It is commonly used in daily life of all classes of citizens and rich farmers to embroider flowers with gold thread, which is also the most popular embroidery.

\section{ANALYSIS OF THE CULTURAL CONNOTATION OF RUSSIAN FOLK EMBROIDERY}

The Russian nation is strong, plain nation that loves the life and its culture is broad and deep with strong idealistic feelings. Integrated the two cultures of the East and West, Russian folk embroidery has a long history, and the practical decorative arts closely related to life have various kinds, long history and excellent and systematic development. People living in the vast land of Russia have a variety of national customs and living habits, so the variety of national culture creates a large number of Russian folk embroidery. In general, the categories of Russian folk embroidery are various, with rich and colorful form, superb skills, primitive style, and luxury feelings; due to the developed industrial, chemical, manufacturing process, material application is very broad, and they can grasp the relationship between material and performance form and the content, so as to use a variety of materials to produce folk art works; practical function (material practical and spirit practical) is still the original intention of embroidery design, and aesthetic features are more prominent with rich artistic expression of works, not limited to one type. The works with strong folk flavor mostly can reflect the national characteristics and real life in Russia. Making full use of local property is a feature of Russian folk embroidery creation, which can also reflect the expressive ability of craftsmen to comprehensively grasp the material and the content of the work.

Because of the unique production process of Russian folk embroidery crafts, the production group has very significant gender differences, with women accounting for more than $99 \%$, becoming the material basis for their life of many families. Developed folk fiber technology in Russia also reflects the important position of Russian women in the social life and the living environment and customs are reflected in the handicrafts. For instance, the cold long winter result in the prevalence of Russian shawl, long-term indoor life makes people pay more attention to the decoration of the room, and the lower fertility indicators makes many people hope that the family is thriving and place their hope on the dolls. Women integrate the broad maternal love into the crafts, so the delicate craftsmanship and soft fiber material give people the feeling of warmth, comfort and consideration. Many dolls with religious and superstitious color express the desire to pray for family prosperity and children's health and happiness. Russian fiber technology continues its traditional folk decorative patterns, decorated with animal images and shape with rich flavor of life. The performance is exquisite, giving people the feelings of luxury and pretty and charming feminine beauty. However, the single raw materials restricted the Russian embroidery to develop towards a richer direction to a certain extent. In some respects, this is the perfect method of preservation of their fiber craft national character.

\section{CONCLUSION}

In short, folk embroidery of Russia, a multi-ethnic country, has a rich folk art resources and deep religious tradition. Russian folk embroidery as the quintessence of material and spiritual culture, its formation and development not only are influenced by regional, national and other objective factors, but also depends on the accumulation of national history, cultural traditions, customs etiquette, religious beliefs and so on. It can be said that the appearance of Russian folk embroidery contains a profound cultural connotation, so only when we understand the artistic characteristics and cultural background associated with its 
appearance can we profoundly understand Russian folk embroidery.

\section{REFERENCES}

[1] Hu Jiancheng. Russian Art. Hebei Education Press, 2003.

[2] Xi Jingzhi. The History of Russian Art. People's Fine Arts Publishing House, 2004.

[3] Zhu Xiaoyue. Industrial Arts and Crafts culture. Shanghai Art and Craft, 87.

[4] H.M. Kalashnikova. Soviet folk art. Jiangsu fine arts publishing house, 1923. 